\title{
Thickness of the buccal bone wall and root angulation in the maxilla and mandible: an approach to cone beam computed tomography
}

\author{
P. López-Jarana' ' C. M. Díaz-Castro², A. Falcão ${ }^{1}$, C. Falcão ${ }^{1}$, J. V. Ríos-Santos ${ }^{3 *}$ (i) and M. Herrero-Climent ${ }^{1}$
}

\begin{abstract}
Background: The objective of this paper is to anatomically describe the bone morphology in the maxillary and mandibular tooth areas, which might help in planning post-extraction implants.

Methods: CBCT images (Planmeca ProMax 3D) of 403 teeth (208 upper teeth and 195 lower teeth) were obtained from 49 patients referred to the Dental School of Seville from January to December 2014. The thickness of the facial wall was measured at the crest, point A, 4 mm below, point $B$, and at the apex, point $C$. The second parameter was the angle formed between the dental axis and the axis of the basal bone.

Results: A total of 403 teeth were measured. In the maxilla, $89.4 \%$ of incisors, $93.94 \%$ of canines, $78 \%$ of premolars and $70.5 \%$ of molars had a buccal bone wall thickness less than the ideal $2 \mathrm{~mm}$. In the mandible, $73.5 \%$ of incisors, $49 \%$ of canines, $64 \%$ of premolars and $53 \%$ of molars had $<1 \mathrm{~mm}$ buccal bone thickness as measured at point $\mathrm{B}$. The mean angulation in the maxilla was $11.67 \pm 6.37^{\circ}$ for incisors, $16.88 \pm 7.93^{\circ}$ for canines, $13.93 \pm 8.6^{\circ}$ for premolars, and $9.89 \pm 4.8^{\circ}$ for molars. In the mandible, the mean values were $10.63 \pm 8.76^{\circ}$ for incisors, $10.98 \pm 7.36^{\circ}$ for canines, $10.54 \pm 5.82^{\circ}$ for premolars and $16.19 \pm 11.22^{\circ}$ for molars.

Conclusions: The high incidence of a buccal wall thickness of less than $2 \mathrm{~mm}$ in over $80 \%$ of the assessed sites indicates the need for additional regeneration procedures, and several locations may also require custom abutments to solve the angulation problems for screw-retained crowns.
\end{abstract}

Keywords: Buccal bone wall thickness, Basal bone angulation, Root angulation, Basal bone, Cone beam computed tomography, CBCT

\section{Background}

According to a prospective study, the majority of bone remodelling occurs after a dental extraction in the buccal plate, with a vertical loss of $1 \mathrm{~mm}$ and a larger degree of horizontal resorption (80-63\%) than vertical (69-65\%) [1]. In addition, the mid-buccal recession of an immediate implant placed into a fresh extraction socket has been reported to be 0.55 to $0.75 \mathrm{~mm}$ at 1 year of follow-up [2].

\footnotetext{
* Correspondence: jvrios@us.es

${ }^{3}$ School of Dentistry. Universidad de Sevilla (Spain), C/Avicena S/N, 41009 Seville, Spain

Full list of author information is available at the end of the article
}

The immediate (after tooth extraction) implant placement protocol [3] has advantages over other early or delayed approaches in the reduction of treatment time and patient discomfort, since it requires fewer surgical procedures. The assessment of the tooth root anatomy helps the clinician to properly choose the best treatment protocol [4]. The thickness of the buccal alveolar bone wall, especially the bundle bone (whose vascularization depends on the periodontal ligament $[5,6])$, undergoes extensive remodelling during the healing of the alveolar process. This influences soft and hard tissue volume and its relationship with the implant, which impact the biological and aesthetic results achieved [7].

(c) The Author(s). 2018 Open Access This article is distributed under the terms of the Creative Commons Attribution 4.0 International License (http://creativecommons.org/licenses/by/4.0/), which permits unrestricted use, distribution, and reproduction in any medium, provided you give appropriate credit to the original author(s) and the source, provide a link to the Creative Commons license, and indicate if changes were made. The Creative Commons Public Domain Dedication waiver (http://creativecommons.org/publicdomain/zero/1.0/) applies to the data made available in this article, unless otherwise stated. 
The planning of an immediate implant requires an intact vestibular wall or a type 1 socket as rated by Elian et al. [8], which means a socket where the vestibular and palatal plates and the overlaying soft tissue are preserved. Furthermore, at least a $2-\mathrm{mm}$ thickness of the vestibular plate is needed for soft tissue stability to prevent prosthetic and aesthetic complications. Many authors suggested that the shoulder of the implant should be placed in the area that they called the comfort zone: 1.5 or $2 \mathrm{~mm}$ apical to the gingival margin of the future restoration [9]. A more buccal position carries a greater risk of recession and restorative difficulties [10]. Placing it too palatal results in an overlapping or over-contouring towards the vestibule. The morphology of the residual alveolar process is also crucial to determine the orientation for implant placement [11]. Carvalho described the bone triangle concept, which consists of the residual basal bone apical to the alveolar process [12]. The implant position could be affected by the angulation of this basal bone triangle, which in turn is vital to achieve primary stability for an immediate implant. The difference between the proper emergence of the implant crown and the ideal angulation of this apical bone triangle should be 10 degrees [13].

Many clinical situations require additional surgical procedures, apart from all the previously mentioned considerations, to make screw-retained prostheses. Apical fenestrations of the bone plate in the anterior maxillary region are common when leading the emergency screwed profile into the palatal zone [14]. Previous anatomic studies have shown deep depressions in the alveolar bone around the apex, which becomes a risky situation, especially in the lateral incisor region due to the limited availability of alveolar bone [15]. However, some clinicians prefer to preserve the thickness of the alveolar process by positioning the implant in the same tooth axis and afterwards restore them with CAD-CAM or standard angulated abutments [16].

CBCT helps to establish the morphologic characteristics of the residual alveolar process [17-19].

The main aim of this study is to anatomically describe the bone morphology in the maxillary and mandibular alveolar bone tooth areas, which might help in planning post-extraction implants. The analysis consists of assessing [1] roots position of remaining teeth in the alveolar process by measuring the distance from the root to the buccal wall at three specific locations, and [2] the angle formed by the axis of the basal bone with the axis of the tooth.

\section{Methods}

The present transversal descriptive study included CBCT images obtained by an x-ray device (Planmeca ProMax 3D; Planmeca Oy; Helsinki, Finland) using a spiral technique with $0.2 \mathrm{~mm}$ thickness $(200 \mu \mathrm{m}$ voxel size, $200 \mathrm{~mm}$ field of view (FOV), $90 \mathrm{kV}, 10 \mathrm{mAs}, 1 \mathrm{~mm}$ pass) from patients referred to the Periodontology Department of Dental School of Seville for implant therapy from January to December 2014. The ethical committee for the University of Seville approved this non-interventional study for the acquisition of the images, number 0159-N-14 (PEIBA) of the Junta de Andalucía, Spain. The inclusion criteria are described in Table 1.

\section{Image process and codification}

The CBCT images used in the present study were selected from the faculty's database and were not specifically acquired for this study. The CBCT images were anonymous and were saved in Digital Imaging and Communications in Medicine (DICOM) format inside a protected computer with specific software for implant planning. The measurements were performed using a commercial image analysis and graphics software (Adobe Photoshop CS5, Adobe Systems Incorporated, 345 Park Avenue, San Jose, California 95, 110, USA) by 3 pre-calibrated surgeons. The captured images of the scan were saved with the standard zoom and resolution of Planmeca Romexis viewer of Planmeca ProMax 3D; and exported to Adobe Photoshop CS5, to be measured.

\section{Examiner calibration}

Three examiners were calibrated using 10 randomized CBCT images on 2 different days, $48 \mathrm{~h}$ apart. The calibration was achieved by blind measurements of the same random teeth by the three examiners, registering the grade of reproducibility. The intra-examiner intraclass correlation coefficient (ICC) were 0.98, 0.97 and 0.98 , and the inter-examiner ICC were 0.99 and 0.98 .

\section{Radiographic image analysis of the CBCTs}

CBCT images were analysed on two computers, both with Windows 7 and Intel core i-7 processors with a monitor resolution of $1366 \times 768$. Data were reconstructed with an image size of $401 \times 401 \times 401$, voxel size $200 \mu \mathrm{m}, 90 \mathrm{Kv}, 14 \mathrm{~mA}, 12,249 \mathrm{~s}$ and DAP 12,3 $\left(\mathrm{mGyxcm}^{2}\right)$.

The arch form selector tool was centred throughout the middle of the arch in the coronal plane at the cement-enamel level selecting the centre of the nerve canal of single root teeth and the middle of the interradicular septum of multirooted teeth (Fig. 1). The thickness of the alveolar bone was measured after selecting the cross-sectional image made at the midpoint of the tooth, at which the centre of the root canal passes, parallel to its long axis (Fig. 2). To perform the measurements, sagittal scans from the reconstructed data were selected, resulting in images where the entire root and 
Table 1 The systemic inclusion and local exclusion criteria

\begin{tabular}{ll}
\hline Systemic inclusion criteria & Local exclusion criteria \\
\hline $\begin{array}{l}\text { 1. Absence of systemic disease of relevant history of bad health (particularly } \\
\text { ruling out bone diseases, uncontrolled or poorly controlled diabetes, unstable } \\
\text { or life-threatening conditions or requiring antibiotic prophylaxis). }\end{array}$ & 1. Radiolucent image greater than 1/3 of the root, metal artefacts. \\
2. Absence of history of radiotherapy or chemotherapy in the past 5 years & $\begin{array}{l}\text { 2. Severe root angulation (selected tooth image was not } \\
\text { contained in slice). }\end{array}$ \\
$\begin{array}{ll}\text { 3. Absence of autoimmune diseases and any drug use. } & \text { 3. Severe root resorption. } \\
\text { 4. Absence of pregnancy or lactation. } & \begin{array}{l}\text { 4. Radiographic evidence of surgical (guided bone/tissue } \\
\text { regeneration) treatment in the anterior maxillary dentition. }\end{array}\end{array}$
\end{tabular}

cementoenamel junction (CEJ) were present for single rooted teeth. Two different slices were selected for multirooted teeth, one which passed across from the apex of the mesiobuccal and the distobuccal root. The long axis determined the slice. The captured images had a resolution of 72 pixels/inch and were saved with the standard zoom of Planmeca Romexis [20] viewer and exported to Photoshop CS5 to be measured. All the images had a lateral ruler which served to the surgeons for calibrating the measurements made on the photo editor to the distance at the DICOM images.

\section{Parameters or variables}

The thickness of the buccal bone wall was measured in a sagittal slice, perpendicular to the long axis of the root (defined by the line from the incisal border to the apex) at several points (Fig. 2):

A: Thickness at the first top coronal part of the buccal crest,

B: Thickness $4 \mathrm{~mm}$ upper from the point A.

C: Thickness at the apex from the apical constriction to the buccal wall.
Measurement of the angle formed by the axis of the basal bone triangle with the axis of the tooth in the upper and lower arches (Fig. 3).

The angle of the basal bone triangle was defined by two reference points in the palatal and vestibular areas at the apex and other two points in the apical part of the basal bone triangle. A perpendicular line passes across these horizontal lines at the middle. With the angle tool, the axis of the tooth and the axis of the basal bone were drawn, and the angle formed in their intersection was determined. The authors have uploaded the Excel data file to the 'idUS' repository of the University of Seville. Available for readers.

\section{Statistical analysis}

The data obtained was introduced in Excel software (Microsoft) to perform a descriptive analysis with the adequate codification of the patients. The data were analysed using SPSS software version 22. Descriptive statistics, including the mean, SD, and 95\% confidence intervals (CIs), were calculated.

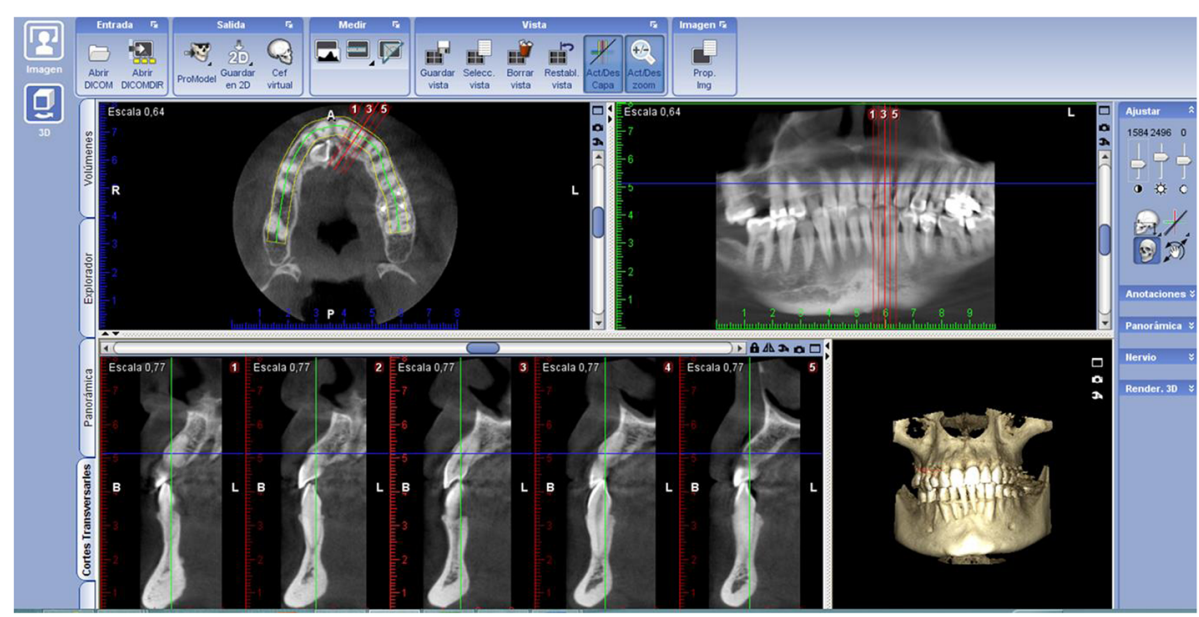

Fig. 1 Selection of the axial slice 


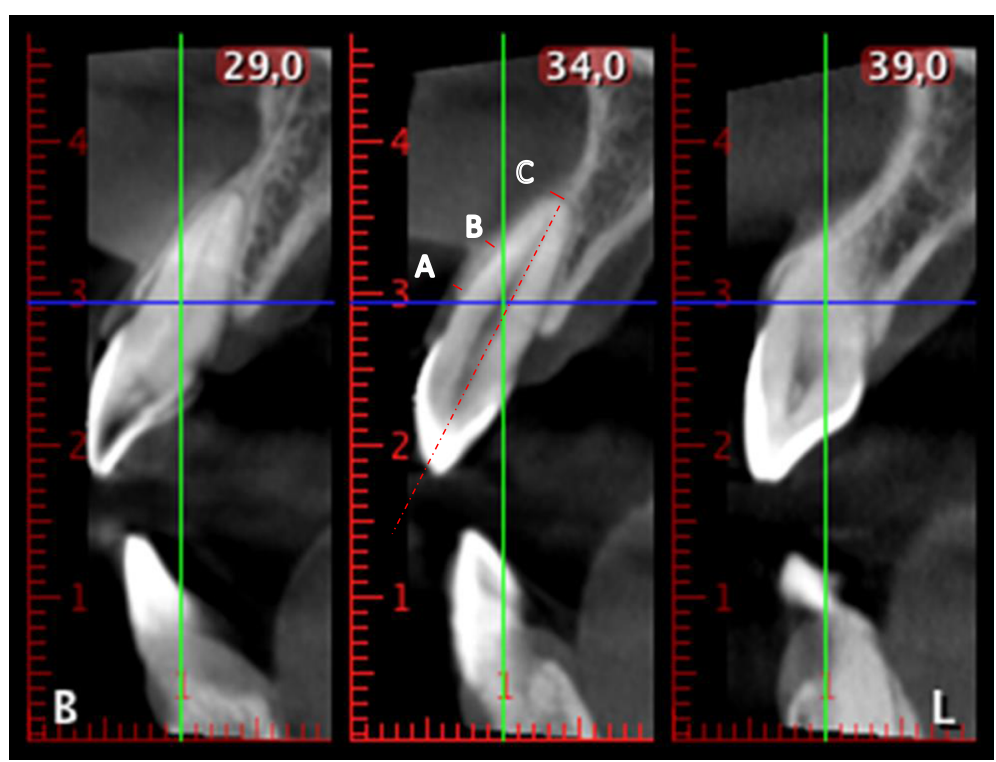

Fig. 2 The thickness of the buccal bone wall. a Thickness at the coronal part of the buccal crest. b Thickness at $4 \mathrm{~mm}$ from the coronal buccal crest. c Thickness at the apex from the apical constriction to the buccal wall

\section{Results}

A total of 49 patients (mean age of 40.3 years) met the inclusion criteria (19 men and 30 women), resulting in a sample of 403 teeth that were measured. Of these, 208 were upper teeth and 195 were lower teeth. In the maxilla, the samples included 32 central incisors, 34 lateral incisors, 33 canines, 25 first and $25 \mathrm{~s}$ premolars, and 31 first and $28 \mathrm{~s}$ molars. In the mandible, the samples included 39 central incisors, 38 lateral incisors, 35 canines, 37 first and $25 \mathrm{~s}$ premolars, and 10 first and $11 \mathrm{~s}$ molars.

\section{The thickness of the buccal bone}

In the maxilla, the buccal alveolar plate of premolars and molars was the thickest, measured at each reference point. Approximately $89.4 \%$ of incisors, $93.94 \%$ of canines, $78 \%$ of premolars and $70.5 \%$ of molars had a thickness lower than the ideal $2 \mathrm{~mm}$ of the buccal alveolar process (Table 2).

In the mandible, the buccal alveolar plate of premolars and molars was also the thickest, measured at each reference point. A mean thickness of the buccal bone of

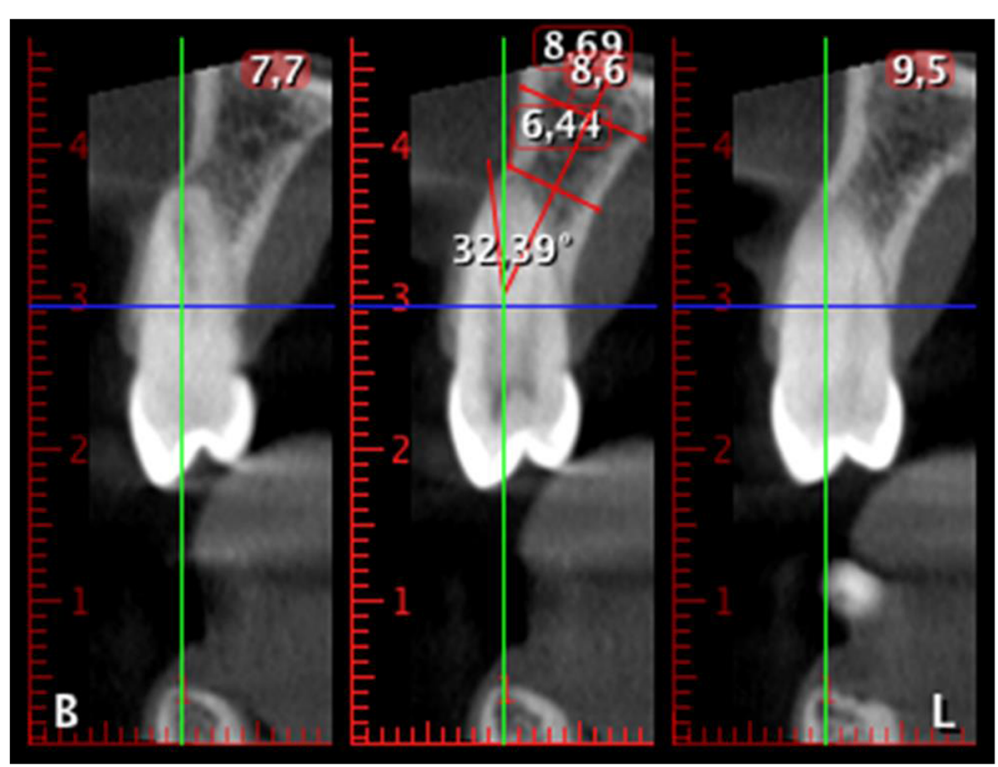

Fig. 3 The angle between the dental axis and the basal bone 
Table 2 Medium values of the thickness of the alveolar process

\begin{tabular}{lllll}
\hline Table 2 & $\mu$ & A & B & $C$ \\
\hline Maxillary incisors & 66 & $1.036 \pm 0.46 \mathrm{~mm}$ & $1.021 \pm 0.49 \mathrm{~mm}$ & $1.614 \pm 0.95 \mathrm{~mm}$ \\
Maxillary canines & 33 & $1.047 \pm 0.39 \mathrm{~mm}$ & $1.27 \pm 1.95 \mathrm{~mm}$ & $1.26 \pm 0.68 \mathrm{~mm}$ \\
Maxillary premolars & 50 & $1.20 \pm 0.67 \mathrm{~mm}$ & $1.43 \pm 0.95 \mathrm{~mm}$ & $2.19 \pm 1.68 \mathrm{~mm}$ \\
Maxillary molars & 59 & $1.240 \pm 0.83 \mathrm{~mm}$ & $1.55 \pm 1.41 \mathrm{~mm}$ & $2.153 \pm 1.68 \mathrm{~mm}$ \\
Mandibular molars & 21 & $0.917 \pm 0.416 \mathrm{~mm}$ & $3.109 \pm 2.03 \mathrm{~mm}$ & $6.779 \pm 2.925 \mathrm{~mm}$ \\
Mandibular premolars & 62 & $0.841 \pm 0.402 \mathrm{~mm}$ & $1.490 \pm 0.97 \mathrm{~mm}$ & $3.814 \pm 1.827 \mathrm{~mm}$ \\
Mandibular canines & 35 & $0.794 \pm 0.407 \mathrm{~mm}$ & $1.079 \pm 0.86 \mathrm{~mm}$ & $3.535 \pm 1.869 \mathrm{~mm}$ \\
Mandibular incisors & 77 & $0.767 \pm 0.361 \mathrm{~mm}$ & $0.936 \pm 0.77 \mathrm{~mm}$ & $3.187 \pm 1.905 \mathrm{~mm}$ \\
\hline
\end{tabular}

$<1 \mathrm{~mm}$ was present in 57 incisors, 24 canines, 40 premolars and $11 \mathrm{M}$ in site $\mathrm{A}$, but this thickness increased to $>2 \mathrm{~mm}$ in 54 incisors, 26 canines, 54 premolars and $12 \mathrm{M}$ in site C. At site A, $74.02 \%$ of the incisors, $68.57 \%$ of canines, $64.51 \%$ of premolars and $57.14 \%$ of molars were $<1 \mathrm{~mm}$ at the first measurement points. To understand the distribution of the bone thickness at the wall, the study sample was divided into two groups: ideal $(\geq 2 \mathrm{~mm})$ and non-ideal thickness $(<1 \mathrm{~mm})$ (Table 3).

\section{The angulation between the axis of the teeth and the alveolar process}

In the maxilla, only 31 of 66 incisors, 6 of 32 canines, 18 of 47 premolars and 32 of $58 \mathrm{M}$ had an angle less than $10^{\circ}$. In the mandible, the maximum angulation was found in some molars $\left(43.26^{\circ}\right)$ and incisors $\left(38^{\circ}\right)$ (Table 4, Figs. 4, 5).

\section{Discussion}

The long-term aesthetic implications of bone remodelling after implant placement are focused in the apical migration of the vestibular gingival margin, a parameter associated with the disappearance of the bundle bone. Therefore, knowledge of the bone dimensions surrounding the tooth are required in order to predict the degree of reabsorption that will occur after tooth extraction and replacement [17]. The underlying surrounding bone morphology of an immediate implant plays a critical role in soft tissue stability and influences the aesthetic outcome with the final restoration [18]. Many factors are responsible for the possible aesthetic risk when immediate implants are placed: the absence of the bundle bone, the remodelling of the alveolar process after tooth extraction, the thickness of the vestibular bone wall, as well as the convexity of the alveolar process because these two parameters influence the emergence profile of the restoration [21].

The related disparity of the CBCT between the true value and the general mean value was $0.8-1 \%$ for width measurements and $2.2 \%$ for height measurements [22]. In our study, the CBCT software used did not allow the measurement of a thicknesses less than $0.8 \mathrm{~mm}$; therefore, we had to use Adobe Photoshop CS5 software to measure lower thickness values, which were then converted to real measures.

In the maxilla, the anatomical descriptive study from Huyn-Va et al. in 2010 [19] employed a sample of 93 extraction sockets to show a wall thickness of less than $1 \mathrm{~mm}$ in $87 \%$ of cases at a coronal level in the portion

Table 3 Distribution of the buccal bone wall thickness in groups

\begin{tabular}{|c|c|c|c|c|c|c|c|c|c|}
\hline \multirow[t]{2}{*}{ Dental group } & \multicolumn{3}{|l|}{$<1 \mathrm{MM}$} & \multicolumn{3}{|l|}{$1-2 \mathrm{MM}$} & \multicolumn{3}{|l|}{$>2 \mathrm{~mm}$} \\
\hline & $A$ & B & C & $A$ & B & C & A & B & C \\
\hline Max Incisors (C, L) & $35(53-53 \%)$ & $32(53-44 \%)$ & $15(13-32 \%)$ & $26(38-41 \%)$ & $31(44-50 \%)$ & $34(59-44 \%)$ & $5(9-6 \%)$ & $3(3-6 \%)$ & $17(28-24 \%)$ \\
\hline Max Canines & $18(45 \%)$ & $19(58 \%)$ & $12(36 \%)$ & $12(30 \%)$ & 13 (39\%) & $17(52 \%)$ & $3(8 \%)$ & $1(3 \%)$ & $4(12 \%)$ \\
\hline $\operatorname{Max} \operatorname{Pm}\left(1^{\circ}, 2^{\circ}\right)$ & $20(54-24 \%)$ & $18(56-16 \%)$ & $12(36-12 \%)$ & 27 (42-64\%) & $21(36-48 \%)$ & $15(28-32 \%)$ & $4(4-12 \%)$ & $10(8-32 \%)$ & $25(36-56 \%)$ \\
\hline $\operatorname{Max} M\left(1^{\circ}, 2^{\circ}\right)$ & $25(45-32 \%)$ & $28(55-39 \%)$ & $19(48-14 \%)$ & $25(45-39 \%)$ & $13(23-21 \%)$ & $15(26-25 \%)$ & $11(10-29 \%)$ & $18(23-39 \%)$ & $25(26-61 \%)$ \\
\hline $\begin{array}{l}\text { Mnd Incisors } \\
\text { (central, lateral) }\end{array}$ & 57 (79-68\%) & $47(62-61 \%)$ & $5(5-8 \%)$ & $20(21-32 \%)$ & $26(33-34 \%)$ & $18(31-16 \%)$ & 0 & $4(5-5 \%)$ & $54(64-76 \%)$ \\
\hline Mnd Canines & 17 (49\%) & 15 (43\%) & $3(9 \%)$ & $2(6 \%)$ & $16(46 \%)$ & $6(17 \%)$ & $16(46 \%)$ & $4(11 \%)$ & $26(74 \%)$ \\
\hline $\begin{array}{l}\text { Mnd Pm } \\
\left(1^{\circ} \mathrm{PM}, 2^{\circ} \mathrm{PM}\right)\end{array}$ & $40(68-60 \%)$ & $23(46-24 \%)$ & $2(5-0 \%)$ & $22(32-40 \%)$ & $23(35-40 \%)$ & $4(5-8 \%)$ & 0 & $16(19-36 \%)$ & $54(84-92 \%)$ \\
\hline $\begin{array}{l}\text { Mnd Molars } \\
\left(1^{\circ} \mathrm{M}, 2^{\circ} \mathrm{M}\right)\end{array}$ & $11(70-36 \%)$ & 0 & 0 & 10 (30-64\%) & $9(80-9 \%)$ & 0 & 0 & $12(20-91 \%)$ & $21(100-100 \%)$ \\
\hline
\end{tabular}


Table 4 Angulation of the alveolar process versus axial teeth axis: group distribution

\begin{tabular}{lllll}
\hline Table 4 & $\mu$ & Median & Min & Max \\
\hline Maxillary Incisors & 66 & $11.67 \pm 6.4^{\circ}$ & $0.70^{\circ}$ & $27.01^{\circ}$ \\
Maxillary Canines & 33 & $16.88 \pm 7.9^{\circ}$ & $2.18^{\circ}$ & $34.20^{\circ}$ \\
Maxillary Premolars & 50 & $13.93 \pm 8.6^{\circ}$ & $0.33^{\circ}$ & $42.60^{\circ}$ \\
Maxillary Molars & 58 & $9.89^{\circ} \pm 4.8^{\circ}$ & $2.13^{\circ}$ & $20.90^{\circ}$ \\
Mandibular Incisors & 77 & $10.64 \pm 8.8^{\circ}$ & $1.06^{\circ}$ & $38.00^{\circ}$ \\
Mandibular Canines & 35 & $10.99 \pm 7.4^{\circ}$ & $2.00^{\circ}$ & $32.78^{\circ}$ \\
Mandibular Premolars & 62 & $10.54 \pm 5.9^{\circ}$ & $2.05^{\circ}$ & $25.35^{\circ}$ \\
Mandibular Molars & 21 & $16.19 \pm 11.2^{\circ}$ & $2.81^{\circ}$ & $43.26^{\circ}$ \\
\hline
\end{tabular}

closest to the cement-enamel junction (CEJ). The current study presents similar results; the thickness of the buccal bone increases from apical to coronal and from the midline to the canine [23].

Our mean results in terms of the thickness of the maxillary buccal bone were as follows: $54.45 \%$ of incisors and canines, $60 \%$ of premolars and $47 \%$ of molars were lower than $1 \mathrm{~mm}$. All values remained between 0.5 and $1.5 \mathrm{~mm}$ with exception of 4 lateral incisors, where the measured thickness was greater than $1.5 \mathrm{~mm}$ [24].

Januario et al. 2011 [25] measured the thickness of the buccal alveolar bone at 1, 3 and $5 \mathrm{~mm}$ apically from the crest in 250 subjects. The values showed that the thickness was always $<1 \mathrm{~mm}$, and in $50 \%$ of the cases, it was inferior to $0,5 \mathrm{~mm}$. In our sample, we found that $53 \%$ of incisors presented a thickness of the buccal wall bone less than $1 \mathrm{~mm}$.

In the prospective study from Hassan-Assaf et al., the buccal wall thickness measured preoperatively at $2 \mathrm{~mm}$ from the crest resulted in median values that were lower than ours $(1.20 \pm 0.67 \mathrm{~mm}): 1,03 \mathrm{~mm}$ for canines and premolars [26].
On the other hand, our results were slightly higher than those of recently published works, where the average values for the upper arch teeth were less than $1 \mathrm{~mm}$ for all sites, and we did not find statistically significant differences between left and right teeth [15, 27-29].

In upper canines and second premolars, we found a thinner buccal bone wall, which seemed to be similar to the results of other studies. For the upper canines, 58 and $56 \%$ of first premolars showed a thickness thinner than $1 \mathrm{~mm}$. Our results are in agreement with those of Rojo et al. [30]. They show that the thickness of the first premolars seems to be less than that of second premolars, although our mean values were lower. The reason for these lower values could be explained by our measurement method with Photoshop CS5.

However, our mean values increased in an apical direction. This may be due to the possible skeletal class differences in the population groups in the study [31].

For the upper molars, our mean values were similar to those of other recent publications. Our results showed that $55 \%$ of upper first molars and $40 \%$ of second molars had thicknesses thinner than $1 \mathrm{~mm}$ [32]. In a specific study of posterior teeth from the maxilla and mandible, the authors show an increasing buccal plate thickness from anterior to posterior and from coronal to apical that was greater in maxillary than in mandibular teeth [33, 34].

As posterior teeth in the mandible and maxilla are sites where immediate implants are also placed, the present study included the assessment of these teeth in addition to anterior teeth.

In the mandible, outcomes were similar except for the more apical points (at $8 \mathrm{~mm}$ from the CEJ), which were lower than our values at the apex level. This could be related to the reference measurement because our midpoint was situated $4 \mathrm{~mm}$ to the crest.

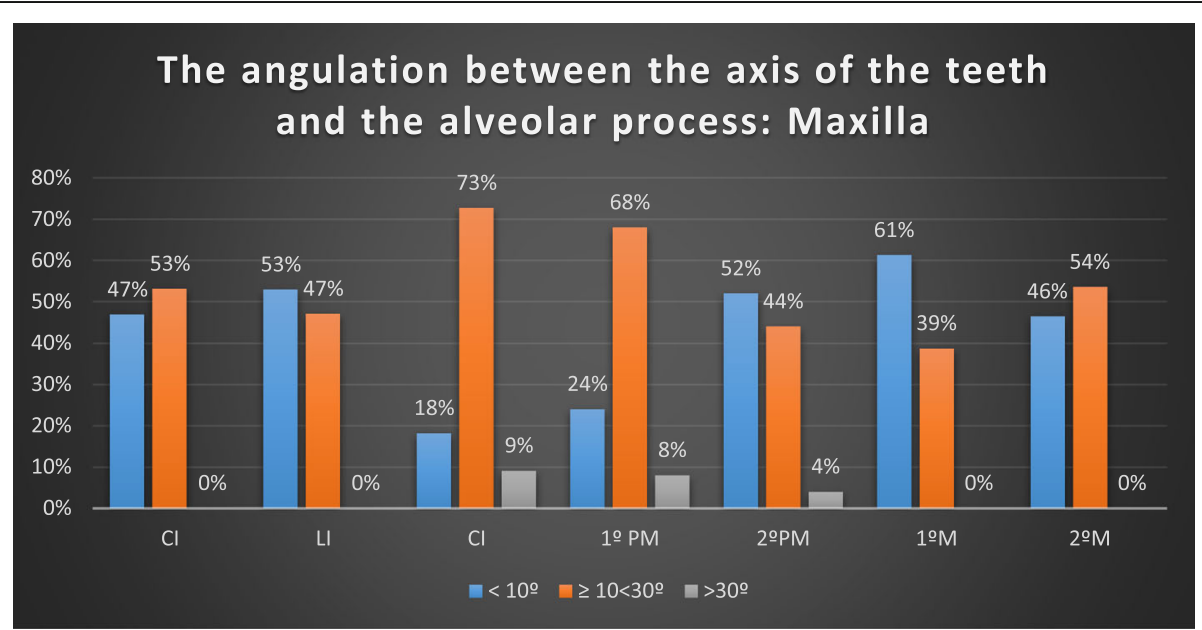

Fig. 4 Angulation of the alveolar process versus the axial superior tooth axis 


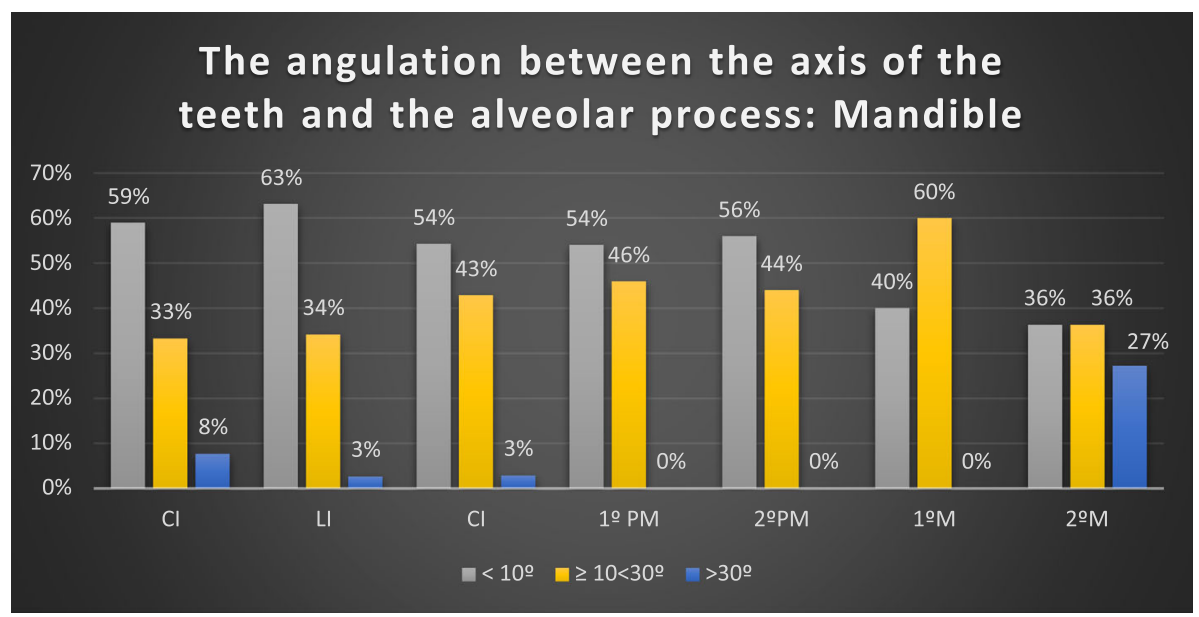

Fig. 5 Angulation of the alveolar process versus the axial inferior tooth axis

In relation to the angle of the root axis and basal bone axis, our research found that in the upper jaw, the mean values were as follows: $11.67 \pm 6.37^{\circ}$ for incisors, $16.88 \pm 7.93^{\circ}$ for canines, $13.93 \pm 8.6^{\circ}$ for premolars, and $9.89^{\circ} \pm 4.8^{\circ}$ for molars. In the mandible, the mean values were $10.63 \pm 8.76^{\circ}$ for incisors, $10.98 \pm 7.36^{\circ}$ for canines, $10.54 \pm 5.82^{\circ}$ for premolars and $16.19 \pm 11.22^{\circ}$ for molars. However, a maximum of $43.26^{\circ}$ was found in some molars and $38^{\circ}$ in some incisors.

According to Nishihara et al., the mean value of the angle of maxillary first premolars was $25.5^{\circ}$ and $18.1^{\circ}$ for second premolars. The insertion angle of the dental implant may leave a depression in the buccal bone that could induce implant protrusion to the vestibular bone in longer implants [35].

According to Kan et al. (2011), the class I type, in which the root is closer to vestibular wall, represents $81.1 \%$ of the cases. These angulations are in most cases greater than $10^{\circ}$ from canine to canine. The sagittal position of the tooth in the alveolar bone is important for the clinician to make decisions for implant-based therapy [11].

In 2014, Wang found differences greater than $10^{\circ}$ in all groups, even up to $42^{\circ}$ in some premolars and upper canines. These differences in the results of angulation were greater than $20^{\circ}$ in $50 \%$ of anterior teeth (and $40 \%$ of the canines $>30^{\circ}$ ). This could be a consequence of the patient's skeletal class [36]. In this study, the sagittal angle formed between the long axis of the tooth and the long axis of the alveolar bone was $<10^{\circ}$ degrees at only $10 \%$ of the teeth in the maxillary aesthetic zone.

In more recent studies, the angulation of the tooth axis is related to the horizontal plane and the buccal bone wall. The more obtuse the angle, the thinner the buccal wall. This situation implies increased risk of perforation of the buccal wall in immediate implant placement [31]. In our opinion, the clinical relevance of these data is that in cases where immediate implants are placed according to bone availability, angulated screwed abutments may be required. In some cases, such as premolars and canines, this might require CAD/CAM-customized components, since available standard angulated screwed abutments are not able to compensate for the resulting discrepancy between angulations. Nevertheless, in the mandible, $8 \%$ of incisors and $27 \%$ of second molars seem to have angulations bigger than $30^{\circ}$ between the basal bone and dental alveolus.

In Lau et al's study, as mentioned previously, the proportion of incisors positioned more buccal (type B) was $78.8 \%$. Furthermore, 19.4 and $1.8 \%$ were positioned midway (type $\mathrm{M}$ ) and more palatal (type P), respectively. This result was in concordance with Kan's study [37]. The position of the teeth must be considered because the anatomy of the dental alveolus increases the difficulty of the ideal positioning of the immediate implant. Sometimes, type 1 Kan's classification means that the teeth are too close to the buccal plate, which is thinner, although palatal bone is preserved and is a suitable zone to achieve bone anchorage.

To our knowledge, no studies have analysed the angulation of mandibular teeth. The mean angulation values between the axis of the teeth and the alveolar process for the mandible were $10.63 \pm 8.76^{\circ}$ in incisors, $10.98 \pm 7.36^{\circ}$ in canines, $10.54 \pm 5.82^{\circ}$ in premolars and $16.19 \pm 11.22^{\circ}$ in molars. However, a maximum of $43.26^{\circ}$ was found in $3 \mathrm{M}$ and $38^{\circ}$ in 30 incisors.

Once the analysis of the studied parameters was completed, we identified the most unfavourable situations for immediate implants: the lateral incisors, canines and premolars in the maxilla and the incisors, canines and second molars in the mandible. 


\section{Conclusions}

There seems to be a link between the angulation of the root and the alveolar axis, which was greater than $10^{\circ}$ in almost all the sites studied.

The thickness of the buccal plate was less than $2 \mathrm{~mm}$ in over $80 \%$ of the teeth studied.

In the maxilla, the most critical areas were the lateral incisors, canines and first premolars, where the thickness of the buccal wall was less than $2 \mathrm{~mm}$ and their angulation with the alveolar process varied between 10 and $30^{\circ}$.

In the mandible, the critical sites were central incisors, lateral incisors, and canines, where the thickness of the buccal wall was less than $2 \mathrm{~mm}$. Furthermore, $27 \%$ of the second molars made an angle with the alveolus of $>30^{\circ}$, but the buccal bone wall thickness was in $91 \%$ of the measured areas. The results of the study could imply that over $80 \%$ of assessed sites could require additional regeneration procedures to preserve hard and soft tissue volumes. Also custom abutments might be necessary to solve the angulation of screw-retained crowns.

\section{Abbreviations}

CAD-CAM: Computer-Aided Design/Computer-Aided Manufacturing: CBCT: Cone Beam Computed Tomography; CEJ: Cementoenamel junction; Cls: Confidence intervals; DICOM: Digital Imaging and Communications in Medicine; FOV: Field of view; ICC: Intraclass Correlation Coefficient; PEIBA: Portal de Ética de la Investigación Biomédica de Andalucía (Spain)

\section{Acknowledgements}

Professor Ana Fernández Palacín, of the Department of Biostatistics in Health Sciences of the University of Seville, collaborated in the analysis of the data.

\section{Funding}

This study was funded by the authors' own institutions

\section{Availability of data and materials}

Available for readers.

\section{Authors' contributions}

L-J P': Data Collection/Analysis/Interpretation. Drafting article. Approval of article. D-CCM: Data Analysis/Interpretation. Critical Revision of article. Approval of article. FA: Data Analysis/Interpretation. Drafting article. Approval of article. FC: Concept/Design, Statistics. Drafting article. Approval of article. R-SJV: Concept/Design. Statistics, Critical Revision of article. Approval of article. H-CM: Concept/Design, Statistics. Critical Revision of article. Approval of article.

\section{Ethics approval and consent to participate}

The ethical committee for the University of Seville approved this noninterventional study for the acquisition of the images, number 0159-N-14 (PEIBA) of the Junta de Andalucía, Spain.

\section{Consent for publication}

The authors have uploaded the Excel data file to the 'idUS' repository of the University of Seville.

\section{Competing interests}

The authors declare that they have no competing interests

\section{Publisher's Note}

Springer Nature remains neutral with regard to jurisdictional claims in published maps and institutional affiliations.

\section{Author details}

${ }^{1}$ Porto Dental Institute, Porto, Portugal. ${ }^{2}$ Marbella Dental, Marbella, Spain. ${ }^{3}$ School of Dentistry. Universidad de Sevilla (Spain), C/Avicena S/N, 41009 Seville, Spain.

Received: 3 August 2018 Accepted: 24 October 2018

Published online: 21 November 2018

\section{References}

1. Sanz M, Cecchinato D, Ferrus J, Pjetursson EB, Lang NP, Lindhe J. A prospective, randomized-controlled clinical trial to evaluate bone preservation using implants with different geometry placed into extraction sockets in the maxilla. Clin Oral Implants Res. 2010;21(1):13-21.

2. De Rouck T, Collys K, Cosyn J. Single-tooth replacement in the anterior maxilla by means of immediate implantation and provisionalization: a review. Int J Oral Maxillofac Implants. 2008;23(5):897-904.

3. Hammerle $\mathrm{CH}$, Chen ST, Wilson TG Jr. Consensus statements and recommended clinical procedures regarding the placement of implants in extraction sockets. Int J Oral Maxillofac Implants. 2004;19(Suppl):26-8.

4. Mandelaris GA, Vence BS, Rosenfeld AL, Forbes DP. A classification system for crestal and radicular dentoalveolar bone phenotypes. Int J Oral Maxillofac Implants. 2013;33(3):289-96.

5. Araujo MG, Lindhe J. Dimensional ridge alterations following tooth extraction. An experimental study in the dog. J Clin Periodontol. 2005;32(2):212-8.

6. Araujo MG, Sukekava F, Wennstrom JL, Lindhe J. Ridge alterations following implant placement in fresh extraction sockets: an experimental study in the dog. J Clin Periodontol. 2005;32(6):645-52.

7. Rossi F, Romanelli P, Ricci E, Marchetti C, Botticelli D. A cone beam tomographic evaluation of hard tissue alterations at immediate implants: a clinical prospective study. Int J Oral Maxillofac Implants. 2013;33(6):815-23.

8. Elian N, Cho SC, Froum S, Smith RB, Tarnow DP. A simplified socket classification and repair technique. Pract Proced Aesthet Dent. 2007;19(2):99-104.

9. Spray JR, Black CG, Morris HF, Ochi S. The influence of bone thickness on facial marginal bone response: stage 1 placement through stage 2 uncovering. Ann Periodontol. 2000;5(1):119-28.

10. Caneva M, Botticelli D, Rossi F, Cardoso LC, Pantani F, Lang NP. Influence of implants with different sizes and configurations installed immediately into extraction sockets on peri-implant hard and soft tissues: an experimental study in dogs. Clin Oral Implants Res. 2012;23(4):396-401.

11. Kan JY, Roe P, Rungcharassaeng K, Patel RD, Waki T, Lozada JL, et al. Classification of sagittal root position in relation to the anterior maxillary osseous housing for immediate implant placement: a cone beam computed tomography study. Int J Oral Maxillofac Implants. 2011;26(4):873-6.

12. Carvalho PF, da Silva RC, Cury PR, Joly JC. Modified coronally advanced flap associated with a subepithelial connective tissue graft for the treatment of adjacent multiple gingival recessions. J Periodontal Res Implant Sci. 2006;77(11):1901-6.

13. Morton D, Chen ST, Martin WC, Levine RA, Buser D. Consensus statements and recommended clinical procedures regarding optimizing esthetic outcomes in implant dentistry. Int J Oral Maxillofac Implants. 2014;29(Suppl):216-20.

14. Leung CC, Palomo L, Griffith R, Hans MG. Accuracy and reliability of conebeam computed tomography for measuring alveolar bone height and detecting bony dehiscences and fenestrations. Am J Orthod Dentofacial Orthop. 2010;137(4 Suppl):S109-19.

15. Zhang W, Skrypczak A, Weltman R. Anterior maxilla alveolar ridge dimension and morphology measurement by cone beam computerized tomography $(\mathrm{CBCT})$ for immediate implant treatment planning BMC Oral Health. 2015;15:65.

16. Pellizzer EP, Falcon-Antenucci RM, de Carvalho PS, Sanchez DM, Rinaldi GA, de Aguirre CC, et al. Influence of implant angulation with different crowns on stress distribution. J Craniofac Surg. 2011;22(2):434-7.

17. Vera C, De Kok IJ, Reinhold D, Limpiphipatanakorn P, Yap AK, Tyndall D, et al. Evaluation of buccal alveolar bone dimension of maxillary anterior and premolar teeth: a cone beam computed tomography investigation. Int J Oral Maxillofac Implants. 2012;27(6):1514-9.

18. Braut V, Bornstein MM, Belser U, Buser D. Thickness of the anterior maxillary facial bone wall-a retrospective radiographic study using cone beam computed tomography. Int J Oral Maxillofac Implants. 2011;31(2):125-31. 
19. Huynh-Ba G, Pjetursson BE, Sanz M, Cecchinato D, Ferrus J, Lindhe J, et al. Analysis of the socket bone wall dimensions in the upper maxilla in relation to immediate implant placement. Clin Oral Implants Res. 2010;21(1):37-42.

20. Pauwels R, Araki K, Siewerdsen JH, Thongvigitmanee SS. Technical aspects of dental CBCT: state of the art. Dentomaxillofac Radiol. 2015:44(1):20140224.

21. Roe P, Kan JY, Rungcharassaeng K, Caruso JM, Zimmerman G, Mesquida J. Horizontal and vertical dimensional changes of peri-implant facial bone following immediate placement and provisionalization of maxillary anterior single implants: a 1-year cone beam computed tomography study. Int J Oral Maxillofac Implants. 2012;27(2):393-400.

22. Mozzo P, Procacci C, Tacconi A, Martini PT, Andreis IA. A new volumetric CT machine for dental imaging based on the cone-beam technique: preliminary results. Eur Radiol. 1998;8(9):1558-64.

23. Fuentes R, Flores T, Navarro P, Salamanca C, Beltran V, Borie E. Assessment of buccal bone thickness of aesthetic maxillary region: a cone-beam computed tomography study. J Periodontal Res Implant Sci. 2015:45(5):162-8.

24. Kim YJ, Park JM, Kim S, Koo KT, Seol YJ, Lee YM, et al. New method of assessing the relationship between buccal bone thickness and gingival thickness. J Periodontal Res Implant Sci. 2016;46(6):372-81.

25. Januario AL, Duarte WR, Barriviera M, Mesti JC, Araujo MG, Lindhe J. Dimension of the facial bone wall in the anterior maxilla: a cone-beam computed tomography study. Clin Oral Implants Res. 2011;22(10):1168-71.

26. Assaf JH, Zanatta FB, de Brito RB Jr, Franca FM. Computed tomographic evaluation of alterations of the buccolingual width of the alveolar ridge after immediate implant placement associated with the use of a synthetic bone substitute. Int J Oral Maxillofac Implants. 2013;28(3):757-63.

27. Farahamnd A, Sarlati F, Eslami S, Ghassemian M, Youssefi N, Jafarzadeh Esfahani B. Evaluation of impacting factors on facial bone thickness in the anterior maxillary region. J Craniofac Surg. 2017;28(3):700-5.

28. El Nahass $\mathrm{H}, \mathrm{NN}$ S. Analysis of the dimensions of the labial bone wall in the anterior maxilla: a cone-beam computed tomography study. Clin Oral Implants Res. 2015;26(4):e57-61.

29. Demircan S, Demircan E. Dental cone beam computed tomography analyses of the anterior maxillary bone thickness for immediate implant placement. Implant Dent. 2015;24(6):664-8.

30. Rojo-Sanchis J, Vina-Almunia J, Penarrocha-Oltra D, Penarrocha-Diago M. Facial alveolar bone width at the first and second maxillary premolars in healthy patients: a cone beam computed tomography study. J Oral Implantol. 2017;43(4):261-5.

31. Khoury J, Ghosn N, Mokbel N, Naaman N. Buccal bone thickness overlying maxillary anterior teeth: a clinical and radiographic prospective human study. Implant Dent. 2016;25(4):525-31.

32. Matsuda H, Borzabadi-Farahani A, Le BT. Three-dimensional alveolar bone anatomy of the maxillary first molars: a cone-beam computed tomography study with implications for immediate implant placement. Implant Dent. 2016;25(3):367-72.

33. Temple KE, Schoolfield J, Noujeim ME, Huynh-Ba G, Lasho DJ, Mealey BL. A cone beam computed tomography (CBCT) study of buccal plate thickness of the maxillary and mandibular posterior dentition. Clin Oral Implants Res. 2016;27(9):1072-8.

34. Braut V, Bornstein MM, Lauber R, Buser D. Bone dimensions in the posterior mandible: a retrospective radiographic study using cone beam computed tomography. Part 1--analysis of dentate sites. Int J Oral Maxillofac Implants. 2012;32(2):175-84.

35. Nishihara K, Yoshimine SI, Goto T, Ishihata K, Kume Kl, Yoshimura T, et al. Topographic analysis of the maxillary premolars relative to the maxillary sinus and the alveolar bone using cone beam computed tomography. Oral Surg Oral Med Oral Pathol Oral Radiol. 2017;123(5):606-12.

36. Wang HM, Shen JW, Yu MF, Chen XY, Jiang QH, He FM. Analysis of facial bone wall dimensions and sagittal root position in the maxillary esthetic zone: a retrospective study using cone beam computed tomography. Int J Oral Maxillofac Implants. 2014;29(5):1123-9.

37. Lau SL, Chow J, Li W, Chow LK. Classification of maxillary central incisorsimplications for immediate implant in the esthetic zone. J Oral Maxillofac Surg. 2011;69(1):142-53,

\section{Ready to submit your research? Choose BMC and benefit from:}

- fast, convenient online submission

- thorough peer review by experienced researchers in your field

- rapid publication on acceptance

- support for research data, including large and complex data types

- gold Open Access which fosters wider collaboration and increased citations

- maximum visibility for your research: over $100 \mathrm{M}$ website views per year

At BMC, research is always in progress.

Learn more biomedcentral.com/submissions 